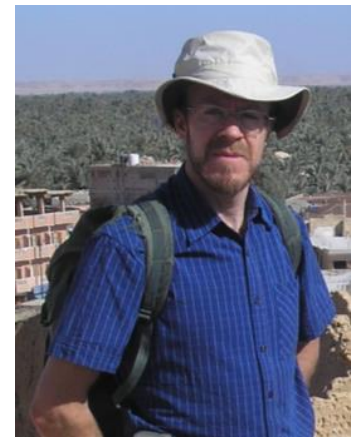

\title{
The importance of interpretive social science to promoting renewable energy and sustainable development
}

\author{
Dr. Steve Connelly \\ Director, PhD Programme Department of Urban \\ Studies \& Planning \\ Department of Urban Studies \& Planning \\ University of Sheffield, Sheffield, United Kingdom \\ Email: S.Connelly@sheffield.ac.uk
}

A few years ago I was privileged to hear one of the UK's leading scientists speak on 'tackling climate change' at my university (Krebs 2010). Lord Krebs is a zoologist, and as Chair of the Adaptation SubCommittee of the UK Government's Committee on Climate Change he has a significant role in advising government on this major challenge of our times. What struck me was that the major challenges he presented demand social science to answer them:

- Wil we switch from talking to doing?

- Are we prepared to elect a Government that is more coercive?

- Are we prepared to stop getting richer and consuming more?

- Wil we invest in technologies for a green prosperous future?

Clearly these are a) crucial b) about politics and society and c) without obvious answers. To be sure, in the field of sustainable development and renewable energy there are many technical issues unresolved: around efficiency and implementation, about what works best in particular settings and so on. This is why the research reported in this journal, amongst others, is so important. But as I understand it the fundamental science in this field is largely known, with a few outstanding exceptions such as light-weight storage of electricity. The Big Questions are social.

One of the papers which has most influenced me was not an academic article, but a project report about failure to achieve an 'obviously' desirable goal: its title was 'Why don't people plant trees?' (Skutsch 1983). This seems to me the fundamental research question. We know sustainable development is important, we know renewables are crucial, but why isn't this knowledge acted on? And who is 'we' in those sentences? And why doesn't the rest of the world listen to 'us'? Scientists and engineers have a tendency to view the answers to this in terms of a combination of ignorance and irrational politics, and so see solutions in terms of transferring knowledge. 'If only they (the public, the government) would listen to our expertise, based in objective scientific knowledge, then everything would be OK.'

There is, however, a great deal of social science - scattered across disciplines such as politics, public administration, sociology, science and technology studies and so on - which explains why this very rational 'deficit model' doesn't work. Weknow that expert knowledge, particularly in application, is often flawed; that disbelief or distrust of those who claim expertise is often rational, based on prior experience; and that many different, equally valid lines of argument and calculations of what really matters are in play in any policy process. Moreover, any technical 'solution' will create winners and losers when put into practice. Sometimes this is obvious: the US administration under President Bush was quite rationally (not simply ideologically) opposed to climate change science, given its links with the oil industry. Sometimes the losers are less visible but perhaps more worthy of our concern: poor farmers who lose their land to biomass crops, or to solar farms. So competing value judgements are always present. 
Investigating how and why policy is developed and is (or isn't) implemented is a crucial step towards addressing Lord Krebs' questions. Taking its theoretical tools from the disciplines listed above, one particular branch of social science has much to offer: interpretive policy analysis. This studies policy making as an interactive process between individuals who are both enabled and constrained by the institutional, cultural, linguistic and material resources available to them. It assumes the (sometimes conflictual) coming together of different motivations and values, and does not assume that one particular form of knowledge will be recognised as necessarily 'better' - in fact a central concern is how different kinds of knowledge are valued and come to be powerful within policy making.

Interpretive policy analysis is well established, though still not the mainstream in policy studies: more prevalent in Europe than in North America, and much less developed elsewhere in the world, although this is changing. This is partly the outcome of academic traditions, and partly also due to the context within which researchers work: for example in the Middle East it is usually harder to access the workings of government than in Europe, with lower expectations that public officials should be open to study by researchers. (Even in Europe this is not necessarily easy: from my own experience local government in the UK is relatively open, but access to observe central government policy making in practice can still be hard to negotiate.)

This has to change. Alongside the continuing investigation of the technical aspects we need scholars worldwide who will investigate policy making for sustainable development and renewable energy alongside the development of technical knowledge. If we are to make the most of the latter we need answers to the questions: what are the institutional barriers to sustainable development? How do ideas about sustainable development get adapted and sometimes watered down? How do other interests and social goals intersect with the sustainable development agenda? And, finally, what might be done differently to enable the necessary changes by governments and communities? My hope is that this journal can play its part in this crucial task.

\section{References}

[1] Krebs, J. (2010) 'Tackling climate change: rhetoric or reality?', the First Sir Hans Krebs Lecture, University of Sheffield, UK, $20^{\text {th }}$ October 2010. http://www.sheffield.ac.uk/polopoly fs/1.84090!/file/KrebsLecturePP-1.pdf

[2] Skutsch, M. M. (1983) Why People Don't Plant Trees: The Socioeconomic Impacts of Existing Woodfuel Programs: Village Case Studies, Tanzania, Washington, D.C.: Resources for the Future.

\section{About Dr. Steve Connelly}

Senior Lecturer at the University of Sheffield's Department of Urban Studies \& Planning, he graduated from Oxford University with a BA in Physics \& Philosophy and then took up a career in overseas development. Having worked in India, Sri Lanka, Sudan and Eritrea, and gained an MSc in Forestry at the Oxford Forestry Institute, he returned to the UK with a commitment to public participation in governance and sustainable development, and an intellectual interest in why these desirable goals are often not achieved. This was the topic of his PhD at the Sheffield Department of Urban Studies \& Planning, where he was appointed as Lecturer in the Department in 2002 and Senior Lecturer in 2011. He is now the Director of the department's doctoral programme - one of the largest and most diverse in its discipline in the UK.

Underlying his research is a concern about what happens to knowledge, and to values of democracy and sustainability, in complex policy making processes. In particular he is intrigued and concerned by how and why apparently widely-valued outcomes do not become dominant: the 'why don't people plant trees?' question. His recent research has examined how academic research is used by central government policy makers, and how different kinds of knowledge are valued within programme evaluation. 